\title{
Brain Abscess Due to Petriellidium boydii
}

\author{
François Dubeau, Louis E. Roy, Johanne Allard, Michel Laverdiere, Suzanne Rousseau, \\ Fernand Duplantis, Jean Boileau, Jacques Lachapelle
}

ABSTRACT: A 22 year-old man died from multiple cerebral abscesses due to Petriellidium boydii $41 / 2$ months after an episode of near drowning. The autopsy showed dissemination to heart and kidney. This patient had no immunocompromising disease but was treated with corticosteroids. The treatment of this condition with ventricular shunting and amphotericin B is discussed and compared with the experience of ten other cases reported in the literature.

RÉSUMÉ: Quatre mois et demi après une quasi-noyade, un jeune homme de 22 ans décède de multiples abcès cérébraux à Petriellidium boydii; l'autopsie révèle une atteinte disséminée touchant le coeur et le rein. Ce patient ne souffrait d'aucune maladie immunodéficiente mais fut traité avec des corticostéroïdes. Les traitements utilisés chez lui, soit la dérivation ventriculaire et l'amphotéricine B font l'objet de la discussion à la lumière de l'expérience des 10 autres cas déjà rapportés dans la littérature.

Can. J. Neurol. Sci. 1984; 11:395-398

Cerebral abscesses due to fungi had been considered to be uncommon. Most cases occur in patients whose resistance has been lowered by disease such as cancer, diabetes mellitus, or immunological deficiency. The widespread use of antibiotics, corticosteroids and immunosuppressive drugs is thought to have contributed to the increased incidence seen in recent years. We report an unusual case of cerebral abscesses due to Petriellidium boydii which occurred in a healthy young man several months after an episode of near drowning.

\section{Case RePOrT}

A previously healthy 22 year-old man was admitted to a local hospital after a motor vehicle accident during which his car fell into a ditch of standing water. Immediately after the accident, it was noted that the patient had lost consciousness and aspirated water. He regained consciousness but progressively became dyspneic. The patient was then transferred to the Hôpital Maisonneuve-Rosemont.

On admission, B.P. was $75 / 60$, pulse 112 per minute, respiration 48 breaths per minute and temperature $39^{\circ} \mathrm{C}$. Superficial lacerations were present on the back and on the arms. There was no obvious sign of trauma to the head, chest or abdomen. Roentgenograms of the chest showed alveolar infiltrates compatible with drowning. There also was moderate to severe anoxia. Aeromonas hydrophila was isolated from a blood culture and the patient was treated with cefoxitin 2 gms every 4 hours and tobramycin $120 \mathrm{mg}$ every 8 hours. Hydrocortisone also was administered intravenously in a dose of $500 \mathrm{mg}$ every 6 hours to quell the pulmonary edema and the chemical inflammation.

On the 26th hospital day, at a time when the radiologic abnormalities in the lungs were improving, the patient developed fever up to $39.5 \mathrm{C}$, headache and nuchal rigidity. Two lumbar punctures showed increased cells (1799-3000 per $\mathrm{mm}^{3}$ with 70-90\% polys), increased protein (1.16-2.04 $\mathrm{g} / \mathrm{l}$ ) and low glucose (both $2.4 \mathrm{mmol} / \mathrm{l})$. CSF cultures were negative for both bacteria and fungi. CT-scan revealed 4 abscesses in the right and left frontal lobes, in the right parietal lobe and in the left paraventricular region (fig. 1).

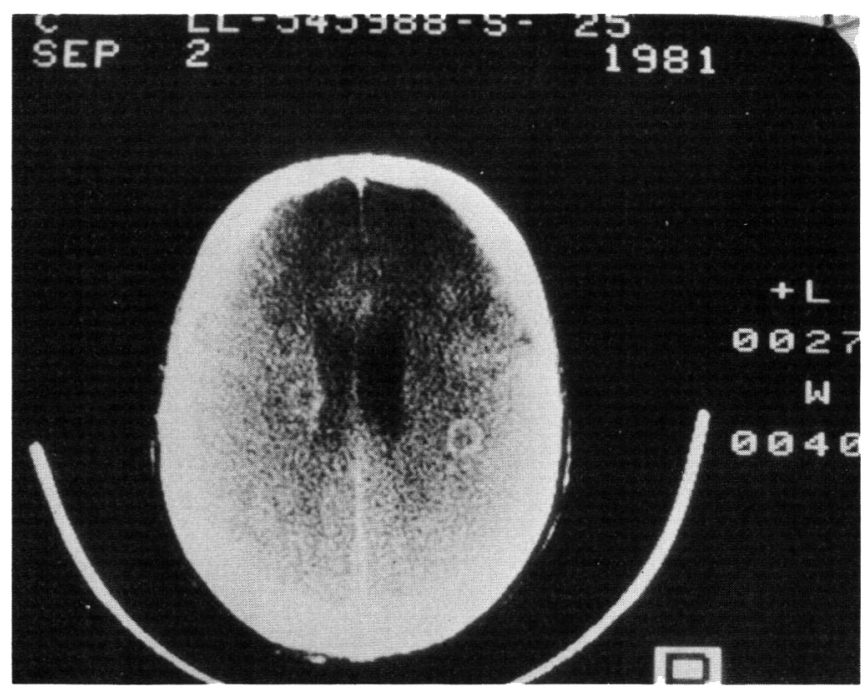

Figure 1 - First CT-Scan 5 weeks after admission showing many abscesses (left paraventricular and right parietal). 
The hydrocortisone and cefoxitin were stopped and the patient was treated with chloramphenicol 1 gm every 6 hours I.V., penicillin G 4 million units every 4 hours I.V. and metronidazole $750 \mathrm{mg}$ q.i.d. p.o. Thirteen days later a control CT-scan showed the abscesses to have increased in size together with a displacement of the midline structures from left to right. A fungal infection was suspected and amphotericin B was started at a progressively increasing dosage to $0.6 \mathrm{mg}$ per $\mathrm{kg}$ per day. Following clinical improvement and because of serious side effects, the antifungal therapy was stopped on day 53.

On the 74th day, the patient developed a right hemiparesis, a right homonymous hemianopia, right sided hypereflexia and a right Babinski sign. Between the 74th and the 106th day, five additional CT-scans showed the same findings as described above plus dilatation of the occipital horn of the left lateral ventricle. Antimicrobial therapy was then modified to provide anti-nocardial (trimethoprim-sulfamethoxazole), anti-anaerobic (chloramphenicol) and antituberculous (isoniazid, rifampicin) activities. Dexamethasone $4 \mathrm{mg}$ every 6 hours I.V. was also started.

On the 106th day, the patient had papilledema. CT-scan showed moderate diffuse dilatation of the lateral and third ventricles. (fig. 2). A ventriculoperitoneal shunt was placed. Eight days later, the shunt had to be revised because of progression of the hydrocephalus. At operation, the shunt was found to be filled with a whitish material which grew after 3 days of incubation at $37^{\circ}$ on a Sabouraud agar a tufted aerial white to grayish mycelium. Microscopic examination revealed branching septate hyphae bearing ovoid conidia at the end and on the sides of conidiophores compatible with the imperfect form of an eumycetes subsquently confirmed by a reference laboratory as being Petriellidium boydii. Amphotericin B was started again both intravenously and intrathecally ( $0.5 \mathrm{mg} /$ day) via external shunts. Amphotericin B was given for one month but the patient continued to deteriorate with coma, tetraplegia and hypothermia. The ventricular dilatation continued to increase. The patient died on day 149.

\section{Autopsy}

Gross examination of the brain showed moderated dilatation of the ventricles and diffuse edema of the white matter. Multiple foci of necrosis and hemorrage were present in the brainstem, cerebellum, corpus callosum and cerebral hemispheres. The ventricles were filled with a gelatinous purulent material. Well circumscribed, encapsulated, yellowish lesions were seen in the white matter of the left frontal lobe, in the white matter adjacent to the left frontal horn and in the cerebellar vermis.

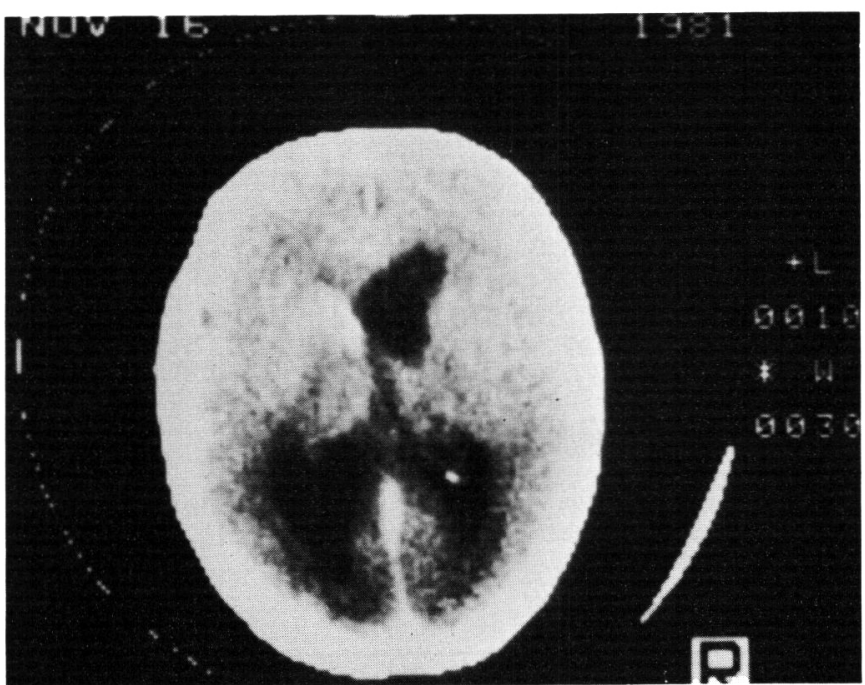

Figure $2-C T$-Scan $31 / 2$ months after admission showing a large left paracentricularabscess, hydrocephalus and shift of the midline structures.
Microscopic examination and cultures of brain material identified Petriellidium boydii. Mycotic abscesses were also found in the left kidney and the myocardium, but no evidence of endocarditis was demonstrated. The lungs showed interstitial bronchopneumonia of the left apex and numerous foreign body granulomas. The rest of the autopsy findings was unremarkable.

\section{Discussion}

Petriellidium boydii, a saprophyte of soil, manure and rotting vegetation is found worldwide. Commonly, it penetrates inside the body either through a superficial wound (Boyd and Crutchfield, 1921) or via the respiratory tract (Arnett and Hatch, 1975; Bakerspigel et al., 1977). In subcutaneous tissues, the fungus proliferates in dense clusters to eventually form a mycetoma (Boyd and Crutchfield, 1921). The other clinical features related to that fungus are known as petriellidiosis (Rippon and Carmicheal, 1976). Petriellidium boydii may be found in pulmonary cavities (Bakerspigel et al., 1977), in paranasal sinuses (Bryan et al., 1980). It may invade the eyes (Ernest and Rippon, 1966; Glassman et al., 1973). It may give rise to necrotizing pneumonia (Saadah and Dixon, 1981), pulmonary abscesses (Woodard, 1982) or a disseminated infection involving central nervous system, thyroid and bones (Davis et al., 1980; Walker et al., 1978; Rosen et al., 1965: Halpern et al., 1977).

Immunocompromised hosts are at risk for systemic dissemination in a manner similar to aspergillosis or mucormycosis (Walker et al., 1978; Winston et al., 1977). Visceral infections in healthy individuals also have been reported (Saadah and Dixon, 1981; Rippon and Carmichael, 1976; Lutwick et al., 1976). The central nervous system rarely is involved. A review of the literature by Fisher et al. (1982) reported eight cases between 1948 and 1982. The total amounts to eleven cases if we include two cases recently described (Fry and Young, 1981; Bryan et al., 1980) plus the present case. Six of these eleven cases, including our own, did not suffer from any underlying immunosuppressive disease. A port of entry for Petriellidium boydii was identified in 5 of these 6 cases, and ironically one of these patients was taken out in "in extremis" from polluted waters in which Petriellidium boydii was isolated (Fisher et al., 1982). The same port of entry is postulated in our patient. The positive blood culture, during the first 24 hours, to Aeromonas hydrophila, a bacterial saprophyte of soil and polluted waters, suggest that the aspirated stagnant water was the source of contamination. Petriellidium boydii likely originated from the same source. Moreover, we can assert that Aeromonas Hydrophila did not take part in the fatal illness, the subsequent 33 negative blood cultures, negative post-mortem cultures, and antibiotic drug sensitivities having shown that the therapy used initially had been efficacious against that bacteria.

Cerebrospinal fluid studies among the eleven patients with central nervous system petriellidiosis showed a cell count between 300 and 2690 per $\mathrm{mm}^{3}$ (mostly polymorphonuclear leucocytes), protein between .63 and $.204 \mathrm{~g} / \mathrm{l}$ and glucose between 1.9 and $4.4 \mathrm{mml} . / \mathrm{l}$. Cultures of the cerebrospinal fluid taken at lumbar puncture were negative except in one case (Benham and Georg, 1948). On the other hand, cerebrospinal fluid taken directly from the ventricular cavities yielded positive culture in all five cases (including the present) in whom it was obtained (Bell and Myers, 1978; Forno and Billingham, 1972; Fry and Young, 1981; Selby, 1972). 
The morbidity and mortality of central nervous system petriellidiosis are both extremely important. The duration of the disease varied from thirty days to nine months with only two of the eleven patients surviving. Evidence of disseminated disease has been observed in 5 cases, among which four were immunosuppressed and one (the present case) had been on corticosteroids for the first 25 days of his hospital stay. These observations suggest that host resistance play an important role in the pathogenicity of Petriellidium boydii. This fact has been amply verified by many authors (Zimmerman, 1955; Baker, 1956; Diamond and Bennett, 1974; Bayer et al., 1976) who have emphasized the growing number of disseminated fungal infections in patients with debilitating underlying diseases and in patients treated with broad spectrum antibiotics and/or corticosteroids.

No therapeutic measure has been singled out in the literature as being curative for Petriellidium boydii, whether these treatments are medical or surgical. Among the medical therapies, both the use of amphotericin B and flucytosin have been unsuccessful (Dixon et al., 1978; Lutwick et al., 1976; Walker et al., 1978). There have been conflicting accounts on the efficacy of a combination of miconazole and surgery '(Fisher et al., 1982; Lutwick et al., 1976; Lutwick et al., 1979; Winston et al., 1977). Surgical measures have been undertaken in the only two surviving cases but some form of surgical treatment (drainage and/or shunt) has been used in 5 of the 9 cases who died (table 1). It would seem that an efficacious and reliable antifungal agent remains to be identified.

\section{REFERENCES}

Arnett JC, Hatch HB (1975) Pulmonary Allescheriasis. Arch. Intern. Med. 135: 1250-1253.

Aronson SM, Benham R, Wolf A (1953) Maduromycosis of the Central Nervous System. J. Neuropathol. Exp. Neurol. 12: 158-168.

Bakerspigel A, Wood T, Burke S (1977) Pulmonary Allescheriasis, Report of a Case from Ontario, Canada. Amer. Journal of Clin. Pathology 68: 299-303.

Baker RD (1956) Pulmonary Mucormycosis. Am. J. Path. 32: 287-313.

Baker AS, Edwards JE, Seidel JS et al (1976) Candida Meningitis. Report of seven cases and review of the english literature. Medicine 55: 477-486.

Bell WE, Myers MG (1978) Allescheria (Petriellidium) boydii. Brain abscess in a child with leukemia. Arch. Neurol. 35: 386-388.

Benham RW, Georg LK (1948) Allescheria boydii, causative agent in a case of meningitis. J. Invest. Dermatology 10: 99-1 10.

Boyd MF, Crutchfield ED (1921) A contribution to the study of mycetoma in North America. Am. J. Trop. Med. 1: 215.

Bryan CS, Di Salvo AF, Kaufman L, Kaplan W, Brill AH, Abbott DC (1980) Petriellidium boydii infection of the sphenoid sinus. Amer. Journal of Clin. Pathology 74: 846-851.

Davis WA, Isner JM, Bracey AW, Roberts WC, Garagusi VF (1980) Disseminated Petriellidium boydii and pacemaker endocarditis. Amer. J. Medicine 69: 929-932.

Deloach ED, Di Benedetto RJ, Hitch WS, Russell P (1979) Southern Med. J. 72: 479-481.

Diamond RD, Bennett JE (1974) Prognostic factors in cryptococcal meningitis. A study in 111 cases. Ann. Intern. Med. 80: 176-181.

Dixon DM, Wagner GE, Shadomy S, Shadomy HJ (1978) In vitro comparison of the antifungal activities of R34,000, Miconazole and Amphotericin B. Chemotherapy 24: 364-367.

Ernest T, Rippon JW (1966) Corneal ulcer due to Allescheria boydii. Am. J. Ophtalmol. 62: 1202-1204.

Table 1: Summary of cases with central nervous system infection from Petriellidium Boydii

\begin{tabular}{|c|c|c|c|c|c|c|c|c|}
\hline 11 & $\begin{array}{l}\text { Benham and Georg, } \\
1948\end{array}$ & $46 / F$ & None & $\begin{array}{l}\text { Lumbar } \\
\text { Puncture }\end{array}$ & Antibiotics & Meningitis & None & Death \\
\hline 21 & $\begin{array}{l}\text { Rosen, Deck et al., } \\
1965\end{array}$ & $19 / \mathrm{F}$ & Glomerulonephritis & Unknown & $\begin{array}{l}\text { Corticosteroids } \\
\text { Immunosuppressants }\end{array}$ & $\begin{array}{l}\text { Brain and thyroid } \\
\text { abscess }\end{array}$ & None & Death \\
\hline 31 & $\begin{array}{l}\text { Forno and } \\
\text { Billingham, } 1972\end{array}$ & $54 / \mathrm{M}$ & $\begin{array}{l}\text { Systemic lupus } \\
\text { Erythematosus }\end{array}$ & Lung & $\begin{array}{l}\text { Corticosteroids } \\
\text { Antibiotics }\end{array}$ & $\begin{array}{l}\text { Brain and thyroid } \\
\text { abscess }\end{array}$ & Surgical drainage & Death \\
\hline 5 & $\begin{array}{l}\text { Winston, Jordan } \\
\text { et al., } 1977\end{array}$ & $57 / \mathrm{F}$ & Acute leukemia & Unknown & $\begin{array}{l}\text { Corticosteroids } \\
\text { Immunosuppressants } \\
\text { Antibiotics }\end{array}$ & Brain abscess & None & Death \\
\hline 6 & $\begin{array}{l}\text { Walker, Adamec } \\
\text { et al., } 1978\end{array}$ & $37 / \mathrm{M}$ & $\begin{array}{l}\text { Glomerulonephritis } \\
\text { Renal allograft }\end{array}$ & Lung & $\begin{array}{l}\text { Corticosteroids } \\
\text { Immunosuppressants }\end{array}$ & $\begin{array}{l}\text { Brain, thyroid, } \\
\text { lung and heart } \\
\text { abscess }\end{array}$ & $\begin{array}{l}\text { Amphotericin B } \\
\text { Flucytosine }\end{array}$ & Death \\
\hline 8 & $\begin{array}{l}\text { Bryan, Disalvo } \\
\text { et al., } 1978\end{array}$ & $47 / \mathrm{F} \mathrm{I}$ & None & Sphenoid sinus & None & $\begin{array}{l}\text { Brain abscess, } \\
\text { sinusitis }\end{array}$ & $\begin{array}{l}\text { Surgical drainage } \\
\text { Miconazole } \\
\text { Amphotericin B }\end{array}$ & Death \\
\hline 9 & $\begin{array}{l}\text { Fry and Young, } \\
1981\end{array}$ & $69 / F \perp$ & None & Unknown & None & Brain abscess & $\begin{array}{l}\text { Surgical drainage } \\
\text { Miconazole }\end{array}$ & Death \\
\hline 10 & $\begin{array}{l}\text { Fisher, Shadomy } \\
\text { et al., } 1982\end{array}$ & $19 / \mathrm{M}$ & None & Lung? & Antibiotics & Brain abscess & $\begin{array}{l}\text { Shunt } \\
\text { Miconazole }\end{array}$ & Death \\
\hline 11 & Dubeau, Roy et al. & $22 / \mathrm{M} \mathrm{N}$ & None & Lung? & $\begin{array}{l}\text { Corticosteroids } \\
\text { Antibiotics }\end{array}$ & $\begin{array}{l}\text { Brain, Kidney and } \\
\text { Heart abscess }\end{array}$ & $\begin{array}{l}\text { Shunt } \\
\text { Amphotericin B }\end{array}$ & Death \\
\hline
\end{tabular}


Fisher JF, Shadomy S, Teabeaut JR, Woodward J, Michaels GE, Newman MA, White E, Seagraves A, Yaghmai F, Rissing JP (1982) Near-drowning complicated by brain abscess due to Petriellidium boydii. Arch. Neurol. 39: 511-513.

Forno LS, Billingham ME (1972) Allescheria boydii infection of the brain. J. Pathol. 106: 195-198.

Fry VG, Young CN (1981) A rare fungal brain abscess in an uncompromised host. Surgical Neurology 15: 446-449.

Glassman MI, Henkind P, Alture-Werber E (1973) Monosporium aprospermum endophtalmitis. Am. J. Ophtalmol. 76: 821-824.

Halpern AA, Nagel DA, Schurman DJ (1977). Allescheria boydii osteomyelitis following multiple steroid injections and surgery. Clin. Orthop. and Related Research 126: 232-234.

Lutwick LI, Galgiani JN, Johnson RH, Stevens DA (1976) Visceral fungal infections due to Petriellidium boydii (Allescheria boydii). In vitro drug sensitivity studies. Amer. J. Med. 61: 632-640.

Lutwick LI, Rytel MW, Yanez JP, Galgiani JN, Stevens DA (1979) Deep infections from Petriellidium boydii treated with Miconazole. JAMA 241: 272-273.
Meyer E, Herrold RD (1961) Allescheria boydii isolated from or patient with chronic prostatitis. Amer. J. Clin. Pathol. 35: 155-159.

Rippon JW, Carmichael JW (1976) Petriellidiosis (Allescheriosis) Four unusual cases and review of literature. Mycopathologia 58: 117-124.

Rosen F, Deck JHN, Rewcastle NB (1965) Allescheria boydii; unique systemic dissemination to thyroid and brain. Canad. Med. Ass. J. 93: $1125-1127$.

Saadah HA, Dixon T (1981) Petriellidium boydii (Allescheria boydii). Necrotizing pneumonia in a normal host. JAMA 245: 605-606.

Selby R (1972) Pachymeningitis secondary to Allescheria boydii. Case report. J. Neurosurg. 36: 225-227.

Walker DH, Adamec T, Krigman M (1978) Disseminated Petriellidosis (Allescheriosis). Arch. Pathol. Lab. Med. 102: 158-160.

Winston DJ, Jordan MC, Rhodes J (1977) Allescheria boydii infections in the immunosuppred host. Amer. J. Med. 63: 830-835.

Woodard BH (1982) Asymptomatic pulmonary coin lesion with Petriellidium boydii. Southern Med. J. 75: 229-230.

Zimmerman JE (1955) Fatal fungus infections complicating other diseases. Am. J. Clin. Pathol. 25: 46-65. 